УДК 616.896-053.6-085.851

DOI https://doi.org/10.26661/2310-4368/2021-2-4

\title{
ВЗАЕМОЗВ'ЯЗОК РІВНЯ СОЦІАЛЬНОЇ ФРУСТРОВАНОСТІ ТА ПОРУШЕНЬ ЕМОЦІЙНОЇ СФЕРИ БАТЬКІВ, ЯКІ ВИХОВУЮТЬ ДІТЕЙ З ОСОБЛИВОСТЯМИ РОЗВИТКУ
}

\author{
Завязкіна Н. В. \\ доктор психологічних наук, доцент, \\ дочент кафедри психодіагностики та клінічної психології \\ Київський національний університет імені Тараса Шевченка \\ вул. Володимирська, 60, Київ, Украӥна \\ orcid.org/0000-0001-5565-8959 \\ nmuz@ukr.net \\ Лисенко І. П. \\ доктор психологічних наук, \\ завідувач кафедри клінічної психології \\ ТОВ «Київський інститут сучасної психології та психотерапї̈» \\ бульв. Лесі Украӥнки, 34, Київ, Україна \\ orcid.org/0000-0002-2749-3461 \\ kispp@i.ua \\ Чигрин О. О. \\ магістр психологіі \\ ТОВ «Київський інститут сучасної психології та психотерапї̈» \\ бульв. Лесі Украӥнки, 34, Київ, Україна \\ orcid.org/0000-0002-2847-8052 \\ alyona.chigrin@gmail.com
}

\begin{abstract}
Ключові слова: дитина, соиіальний захист, фрустрація, емочійна сфера, психодіагностика, розлади аутистичного спектру, синдром Дауна, дитячий иеребральний параліч.
\end{abstract}

В статті розкрито актуальну тему особливостей емоційної сфери батьків, які виховують дітей 3 особливими потребами, та їх взаємозв'язок 3 соціальною фрустрованістю. Заявлена в дослідженні тема є надзвичайно актуальною та комплексною, адже допомога таким родинам в Україні робить свої перші впевнені кроки. Почали формуватися моделі психологічної допомоги батькам «особливих» дітей. За даними деяких документів, а саме «Familie sand Disability» від ОOH, з проблемою інвалідності стикається кожна четверта сім'я. Що стосується України, то за даними статистики, кожного року кількість інвалідів молодого віку, враховуючи інвалідів 3 дитинства, збільшується. Державний комітет у справах сім’ї та молоді поширив інформацію, згідно з якою, на кожні десять тисяч дітей, сто дітей мають різні функціональні обмеження. Велике емоційне навантаження приходиться на батьків дітей 3 інвалідністю та особливостями розвитку. Батьки, у яких з'являється дитина з особливостями розвитку, повністю змінюють та часом суттєво зменшують коло своєї соціальної взаємодії. Народження «особливої» дитини є критичною ситуацією в житті батьків. Саме такий психологічний феномен розглядається як соціальна фрустрованість. Тема соціальної фрустрованості та порушень емоційної сфери у батьків, які виховують дітей з особливостями розвитку, безумовно є актуальною та значущою, в контексті знаходження методів психологічної допомоги. 
Причини порушень, які пов'язані 3 особливостями психічного стану дитини з особливостями розвитку, виступають тривалим психологічно травмуючим фактором для батьків. Метою психологічної роботи 3 батьками дітей $з$ особливостями розвитку $є$ не стільки усунення вже існуючих сімейних проблем, скільки допомога батькам щодо оволодіння методами виявлення та вирішення своїх негараздів.

Таким чином, організація психологічної допомоги сім'ям, які займаються вихованням дітей $з$ особливостями розвитку потребує комплексного модельного підходу, який буде передбачати взаємозв'язок різних напрямів роботи: психолого-педагогічного, корегуючого, розвиваючого, а також уде включати освітню роботу з батьками дитини.

\title{
RELATIONSHIP BETWEEN THE LEVEL OF SOCIAL FRUSTRATION AND DISORDERS OF THE EMOTIONAL SPHERE OF PARENTS WHO RAISE CHILDREN WITH DEVELOPMENTAL FEATURES
}

\author{
Zavyazkina N. V. \\ Doctor of Psychological Sciences, Associate Professor, \\ Associate Professor at the Department of Psychodiagnostics and Clinical Psychology \\ Taras Shevchenko National University of Kyiv \\ Volodymyrska str., 60, Kyiv, Ukraine \\ orcid.org/0000-0001-5565-8959 \\ nmuz@ukr.net \\ Lysenko I. P. \\ Doctor of Psychological Sciences, \\ Head of the Department of Clinical Psychology \\ Kyiv Institute of Modern Psychology and Psychotherapy \\ orcid.org/0000-0002-2749-3461 \\ Lesya Ukrainka Boulevard, 34, Kyiv, Ukraine \\ kispp@i.ua \\ Chigrin O. O. \\ Master of Psychology \\ Kyiv Institute of Modern Psychology and Psychotherapy \\ Lesya Ukrainka Boulevard, 34, Kyiv, Ukraine \\ orcid.org/0000-0002-2847-8052 \\ alyona.chigrin@gmail.com
}

Key words: child, development, social protection, frustration, emotional sphere, psychodiagnostics, autism spectrum disorders, Down syndrome, cerebral palsy.
The article reveals the topical issue of the emotional sphere of parents raising children with special needs, and their relationship with social frustration. The topic stated in the study is extremely relevant and complex, because helping such families in Ukraine is making its first confident steps. Models of psychological assistance to parents of "special" children began to take shape. According to some documents, namely the "Familie sand Disability" from the UN, every fourth family faces the problem of disability. As for Ukraine, according to statistics, every year the number of young people with disabilities, including children with disabilities from childhood, increases. The State Committee for Family and Youth Affairs has disseminated information that for every ten thousand children, one hundred children have various functional 
limitations. Parents of children with disabilities and developmental disabilities have a great emotional burden. Parents who have a child with special needs completely change and sometimes significantly reduce the range of their social interaction. The birth of a "special" child is a critical situation in the life of parents. It is this psychological phenomenon that is seen as social frustration. The topic of social frustration and emotional disorders in parents raising children with special needs is certainly relevant and significant in the context of finding methods of psychological care.

The causes of disorders, which are associated with the peculiarities of the mental state of a child with developmental disabilities, are a long-term psychologically traumatic factor for parents. The purpose of psychological work with parents of children with special needs is not so much to eliminate existing family problems, but to help parents to master the methods of identifying and resolving their problems.

Thus, the organization of psychological assistance to families raising children with special needs requires a comprehensive model approach, which will include the relationship of different areas of work: psychological and pedagogical, corrective, developmental, as well as include educational work with the child's parents.

На сьогоднішній день, для багатьох країн світу, тема інвалідності є однією з актуальніших. Так, за даними $\mathrm{OOH}$, що відображено в документі «Familie sand Disability», $з$ проблемою інвалідності стикається кожна четверта сім'я. Що стосується України, то за даними статистики, кожного року кількість інвалідів молодого віку, враховуючи інвалідів 3 дитинства, збільшується.

Державний комітет у справах сім’ї та молоді поширив інформацію, згідно з якою, на кожні десять тисяч дітей, сто дітей мають різні функціональні обмеження. Проте, при правильному догляді, психологічному супроводі та відповідних умовах реабілітації, можна підвищити їх якість життя.

Велике емоційне навантаження приходиться на батьків дітей з інвалідністю та особливостями розвитку. Тому тема соціальної фрустрованості та порушень емоційної сфери у батьків, які виховують дітей з особливостями розвитку $є$ актуальною та значущою, в контексті знаходження нових методів психологічної допомоги.

Метою психологічної роботи з батьками дітей 3 особливостями розвитку є не тільки усунення вже існуючих сімейних проблем, а й допомога батькам оволодіти методами виявлення та вирішення психологічних труднощів.

Мета. Виявити взаємозв'язок між рівнем соціальної фрустрованості та порушеннями емоційної сфери у батьків, які виховують дітей з особливостями розвитку.

Постановка проблеми. Тема родин, які виховують дітей 3 особливими потребами, завжди була надзвичайно актуальною та важливою, адже допомога таким сім'ям передбачає довготривалу та комплексну роботу чималої кількості спеціа- лістів. Допомога таким родинам в Україні робить свої перші впевнені кроки. На основі цього почали формуватися моделі психологічної допомоги батькам «особливих» дітей [1].

Дослідженням психологічних особливостей родин, у яких зростають діти з особливостями розвитку, в різні періоди займалися такі дослідники, як О. О. Будковська, І. С. Шишова, Д. Б. Усик, Г. М. Федоришин, І. С. Макаренко, Я. С. Білень, Н. О. Майструк, В. С. Стадник, Я. К. Юрків, Л. В. Акатова, Н. Б. Грабовенко, Л. М. Шипіцина, Н. В. Заверико та інші, які цікавились дослідженням широкого кола проблем.

Зокрема, на думку Н. В. Заверико, тема психічних розладів непсихотичного характеру у батьків дітей, які страждають на розлади аутистичного спектру (РАС) та дитячо-церебральний параліч (ДЦП), є однією з найменш досліджених аспектів клінічної психіатрії. Дослідження клініко-психопатологічної діагностики показали, що ті батьки, які займаються вихованням дітей з РАС мають нижчий рівень емоційних та поведінкових розладів, ніж ті батьки, які виховують дітей з атиповим аутизмом [2].

I. В. Макаренко в своїх роботах зазначає, що члени родини, в яких виховуються тяжкохворі діти 3 розладами психіки та РАС, мають меншу схильність до запропонованої психотерапевтичної та медикаментозної допомоги. До того ж, на сьогоднішній день, немає досконалої програми комплексної діагностики та лікування батьків дітей з ДЦП та РАС [3].

Грабовська С.Л. в своїх працях робить акцент на тому, що родини, які займаються вихованням дітей $з$ аутизмом та дитячо-церебральним паралічем, вимушені активно займатися пошуком інфор- 
мації, яка буде для них корисною, з метою покращення функціональних характеристик дитини в буденному житті. Проте, корекційна робота 3 ними обмежена можливістю надання догляду дитині, забезпеченням освітньої інформації та індивідуальними консультаціями [4].

Сім'ї, в яких батьки виховують дітей, проходять важкий шлях, який часто супроводжується кризами. Практично кожна сім'я, яка має дитину 3 особливими потребами, переживає кілька основних фаз кризи:

1 фаза - невідомість, невизначеність. Ця фаза кризи для батьків, яка характеризує стан панічного жаху перед невідомим, переживання шоку, відчуття того, що руйнується «нормальне» життя.

2 фаза - популярність, визначеність. Ця фаза характеризується суперечливістю між «так» на рівні раціонального розуміння (формальну згоду 3 фактом порушення розвитку дитини) і «ні» на рівні почуттів (імпліцитне заперечення).

3 фаза - агресія. У цій фазі кризи у батьків відбувається прорив негативних емоцій на зовні у вигляді спалаху, метушні, агресії, спрямованої на весь навколишній світ.

4 фаза - активна хаотична діяльність. В цей час члени родини активно намагаються виправити ситуацію, що склалася, усіма можливими способами та коштами.

5 фаза - депресія. Усвідомивши безглуздя всіх зусиль в попередній фазі, батьки впадають у відчай, переживають почуття безвиході та апатії.

6 фаза - прийняття факту порушення розвитку. Ця фаза характеризується тим, що батьки знову знаходять сенс життя, бачать можливість подальшого «нормального» життя разом 3 особливою дитиною.

7 фаза - активізація. У батьків з'являються сили для активної побудови та здійснення життєвих планів.

8 фаза - солідарність. Батьки спрямовують свої зусилля на суспільно значущі проблеми,об'єднуються 3 іншими батьками, які мають аналогічні труднощі [5].

Продовжуючи досліджувати кризові фази в таких сім'ях, Н.В. Грабовенко вважає, що відсутність родинного тепла змінює особистісну сферу дитини, формуючи, замість позитивно стійких рис характеру, необхідних для успішної адаптації в соціумі, неадекватні особистісні характеристики. Взаємодія дітей з соціальним середовищем без батьківської любові та підтримки, набуває неадекватних форм і веде до виникнення комунікативних проблем. Відносини з людьми фарбуються, в свідомості дитини, в несприятливі відтінки: відгородженість, тривожність, агресію [5].

В результаті появи дитини 3 особливими потребами, контакти з соціальним оточенням та, безпосередньо, всередині сім’і, суттєво видозмінюються, або взагалі, припиняються. Причини порушень, які пов'язані 3 особливостями психічного стану дитини 3 особливостями розвитку, виступають тривалим психологічно травмуючим фактором для батьків. Таким чином, батьки залишаються один на один зі своїм горем. Їхній психологічний стан $є$ надзвичайно тяжким та можна охарактеризувати, як безвихідне становище.

О. М. Романчук вважає, що поява «особливої дитини» батьками сприймається як справжнє горе та трагедія. Факт народження дитини «не такої, як у всіх» виступає сильним стресором для батьків, а особливо для матері. Пролонгований стрес має деформуючий сильний вплив на психічний стан батьків дитини та є точкою відліку зміни життєвого родинного устрою [6].

Лідерс А.Г. після тривалого вивчення проблем, які виникають в сім'ях вихованців спеціальних установ, і спостереженням за їх дозвіллям, мав змогу виявити ще одну особливість подолання проблем розвитку «особливої» дитини. Такий тип подолання труднощів можна охарактеризувати як безініціативний. Батьки думають, що їхньою «особливою» дитиною повинні займатися співробітники організації, в якому вона виховується, навчається або тривало лікується і живе [7].

Таким чином, більшість дослідників підкреслює, що батьки, у яких з'являється дитина 3 особливостями розвитку, повністю змінюють та суттєво зменшують коло своєї соціальної взаємодії. Народження «особливої» дитини $\epsilon$ критичною ситуацією в житті батьків. Даний феномен розглядається як соціальна фрустрованість та відображений в працях А. Й. Ваврик, О. М. Ходаківської, В. С. Стадник, М. Б. Химко, I. В. Чухрій, А. А. Корочанської, О. Р. Лемещенко, Л. В. Дзюбко, В. І. Очеретянко, О. В. Склянська, О. Б. Гаєвська та інших.

Термін «фрустрованість» використовують у різних теоріях та концепціях в світлі досліджень поведінкової, мотиваційної, емоційно-вольової та діяльністної сфер особистості. Чинниками фрустрованості можуть бути як зовнішні, так i внутрішні обставини. Найчастіше відмічають фрустрованість, як наслідок впливу зовнішніх обставин. Обов'язковими характеристиками соціальної фрустрованості, як поведінкової ситуації, Ф. Є. Василюк вважає наявність вираженої особистісної зацікавленості та заохочення досягти певної мети і тієї перепони, яка перешкоджає даному досягненню [8].

Соціальна фрустрованість, як досить складне психологічне явище, має особистісний та надособистісний характер та виявляється в характерних рисах емоційних переживань i поведінки, та викликається об'єктивно непере- 
борними труднощами, які виникають на шляху до досягнення мети.

Ткачова В.В. зазначає, що об'єктивним предметом стресу, який фруструє батьківську психіку, $\epsilon$ сам факт народження дитини з особливостями розвитку та стан ï здоров'я в майбутньому. Ситуація, яка сформувалася, стає справжнім випробуванням для перевірки почуттів членів родини. Відомі випадки, коли подібні труднощі згуртовували та об'єднували родину. Проте, частина родин не витримують такого випробування i розлучаються, що здійснює сильний негативний вплив на процес формування особистості та психіки дитини з порушеннями розвитку По мірі дорослішання дитини 3 обмеженими можливостями здоров'я, змінюється і направленість соціальних контактів ii сім'ї. Потреба вирішувати проблеми здоров'я, навчання і виховання дитини 3 обмеженими можливостями включає в близьке коло соціальних контактів сім'ї лікарів, педагогів та інших фахівців. 3 моменту влаштування дитини в спеціальну освітню організацію, сім'я дитини з обмеженими можливостями розширює коло своїх знайомств за рахунок спілкування 3 такими ж сім'ями [9].

Виклад основного матеріалу дослідження. Батьки дітей 3 обмеженими можливостями здоров'я, як правило, знаходяться в стані не тільки психологічної, але і соціальної дезадаптації: хвороба дитини докорінно змінює, а іноді і порушує не тільки психологічний клімат, а й уклад, хід життя всієї родини. Змінюються як відносини всередині сім'ї, буває, що доходить до розлучення подружжя, так і контакти із зовнішнім світом: через страх і сором батьків, а також дефіцит часу, як правило, контакти 3 зовнішнім світом максимально звужуються. На цьому фоні розвивається соціальна фрустрованість [1].

Організація психологічної допомоги сім'ям, які займаються вихованням дітей з особливостями розвитку потребує комплексного модельного підходу, який буде передбачати взаємозв'язок всіх напрямів роботи: психолого-педагогічну допомогу, розвивальні та корекційні заняття та освітню роботу з батьками дитини.

У дослідженні прийняли участь 90 батьків дітей 3 особливостями розвитку (30 батьків дітей 3 синдромом Дауна, 30 батьків дітей з розладами аутистичного спектру (РАC) та 30 батьків дітей 3 дитячим церебральним паралічем (ДЦП), віком від 20 до 50 років.

Батькам було запропоновано авторську анкету, а також психодіагностичні методики, зокрема: шкалу вимірювання тривоги Тейлора, опитувальник «Самопочуття, активність, настрій», методику діагностики рівня соціальної фрустрованості, методику «Прогноз» (для оцінки рівня нервово-психічної стійкості), та госпітальну шкалу тривоги і депресії (HADS). Для узагальнення даних було використано відповідні статистичні методи за допомогою програми Jamovi.

За допомогою методу анкетування, шляхом узагальнення заповнених анкет, було одержано об'єктивну інформацію про особисті дані досліджуваних, які свідчать, що найбільшій кількості досліджуваних було від 18 до 28 років; найменше тих, кому було більше 60 років. Вік дітей був: від 0 до 5 років - 42\%, від 6 до 18 років - $40 \%$ і найменше дітей віком від 12 до 21 року.

При аналізі рівня соціальної фрустрованості загалом по вибірці батьків, було отримано результати, які свідчать про те, що у $12 \%$ досліджуваних спостерігався дуже високий рівень соціальної фрустрованості; підвищений рівень був відмічений у $38 \%$ досліджуваних; помірний рівень у $37 \%$ досліджуваних. У $13 \%$ соціальна фрустрованість була виражена незначним чином. Якісний аналіз даних по твердженням методики на виявлення рівня соціальної фрустрованості виявив, що підвищений рівень простежувався за шкалою «Можливість проводити відпустку», що є цілком логічним та передбачуваним, адже залишити дитину з особливостями розвитку, навіть дорослого віку, як правило, не має можливості, навіть на короткий проміжок часу. Також підвищений рівень соціальної фрустрованості відмічався за шкалою «Житлово-побутові умови». Помірний рівень фрустрованості спостерігався за шкалами «Задоволеність способом життя в цілому», «Проведення дозвілля», «Матеріальний стан», «Сфера послуг і побутове обслуговування» та «Взаємини у сім'ї». Низький рівень та/або відсутність проявлень соціальної фрустрованості отримано за шкалами «Можливість вибору місця роботи», «Обстановка в суспільстві(державі)», «Взаємини 3 друзями, найближчими знайомими», «Взаєминами $з$ батьками».

При порівнянні між групами батьків було виявлено наступне. При оцінці рівня фрустрованості у батьків дітей з ДЦП було виявлено, що підвищений рівень фрустрованості відмічався у $43 \%$ досліджуваних; 3 них у 12\% він був дуже високий. Такі батьки знаходились у тяжкому емоційному стані та потребували кваліфікованої психотерапевтичної допомоги.

У батьків дітей з РАС відмічено підвищений рівень соціальної фрустрованості у $41 \%$ випадків. Помірний рівень соціальної фрустрованості було відмічено у $35 \%$ батьків. Вони були здатні самостійно та вчасно контролювати свої емоції. У 24\% соціальної фрустрованості виявлено не було.

У батьків дітей 3 синдромом Дауна також переважав підвищений рівень соціальної фрустрованості (60\%), як і у батьків дітей з РАС. İx 
емоційний стан міг супроводжуватися різкими коливаннями настрою та емоційною нестійкістю.

Отже, було виявлено, що у батьків 3 підвищеним рівнем фрустрованості можуть виникати найрізноманітніші почуття, такі як провина, тривога, напруга, байдужість, лють і ворожість, заздрість, ревнощі. Їм важко соціалізуватися у суспільстві, вони намагаються уникати стигматизуючих подій та внаслідок цього очікування не завжди здатні оцінити соціальну ситуацію об' єктивно.

3 метою оцінки рівня нервово-психічної стійкості нами було використано методику «Прогноз». Результати дослідження показали, що у 51\% батьків дітей з РАС рівень нервово-психічної стійкості задовільний, тобто прояви нервово-психічної стійкості більш за все можливі тільки в непередбачуваних (екстремальних) ситуаціях. У батьків дітей 3 синдромом Дауна, позитивна нервово-психічна стійкість відмічалась в 46\% випадків, тобто прогноз є більш сприятливий. У батьків дітей з ДЦП в 45\% випадків було відмічено незадовільну нервово-психічну стійкість. Даний стан може бути небезпечним та свідчить про те, що батьки знаходяться у доволі тяжкому емоційному стані та потребують кваліфікованої психологічної допомоги.

При оцінці показників за методикою САН важливим виявився показник настрою, який у більшості досліджуваних (47\%) свідчив про ознаку подавленості; нормальний відмічався у 36\%, а гарний настрій простежувався лише у $18 \%$ досліджуваних. Ці дані співвідносилися 3 аналізом даних методики HADS, які вивили завищений показник по шкалі «Субклінічно виражена тривога та депресія» у 55\% досліджуваних.

Щодо дослідженні рівня тривожності в трьох групах батьків, слід зазначити, що в усіх трьох групах переважав високий рівень тривожності (52\%), що говорить про те, що у досліджуваних можуть проявлятися симптоми невротичного конфлікту, емоційні і невротичні прояви.

Помірний рівень ситуативної тривожності виявлено у $37 \%$ батьків, що може бути пояснено тим, що у даної частини досліджуваних рівень ситуативної тривожності знаходиться в межах норми і вони не є надто емоційними та не сприймають хворобу дитини як горе, намагаються зберігати позитивний настрій.

Навпаки, низький рівень тривожності може бути, також, результатом витіснення батьками тривог, 3 метою показати себе в «кращому світлі».

Для досягнення мети дослідження було вирішено дослідити чи існує взаємозв'язок між рівнем соціальної фрустрованості та порушеннями емоційної сфери батьків. Для цього було застосовано відповідні статистичні методи, зокрема, метод кореляційного аналізу Пірсона, в результаті чого було отримано значення $\mathrm{r}=0,477$, яке говорить про наявність середнього зв'язку між перемінними. Тобто у більшості досліджуваних простежується зв'язок між високим рівнем соціальної фрустрованості та несприятливим станом самопочуттям. Високий рівень соціальної фрустрованості впливає на виникнення поганого самопочуття, та погане самопочуття може бути причиною виникнення високого рівня соціальної фрустрованості.

Наступним етапом аналізу стало виявлення взаємозв'язку між високим рівнем соціальної фрустрованості та нервово-психічною стійкістю та отримано значення лінійної кореляції $\mathrm{r}=-0,052$, що свідчить про відсутність зв'язку між високим рівнем соціальної фрустрованості та незадовільною нервово-психічною стійкістю.

Досліджуючи взаємозв'язок між високим рівнем соціальної фрустрованості та високим рівнем тривожності було отримано значення $\mathrm{r}=-0,138$, що свідчить про слабкий зв'язок між перемінними. На основі проведеного статистичного аналізу отриманих даних, можна зробити висновок, що значущий зв'язок простежувався тільки між високим рівнем соціальної фрустрованості та несприятливим станом самопочуття.

Висновки. Таким чином, провівши емпіричне дослідження та зібравши статистичні дані, можна зазначити, що у батьків дітей з особливими потребами спостерігався високий рівень соціальної фрустрованості та тривожності, ознаки проявів депресивного кола, несприятливий стан самопочуття та настрою на момент дослідження.

Виявлені результати надають змогу зробити висновок, що умови життя батьків дітей з особливими потребами зумовлюють постійну напругу, переживання, емоційне та фізичне навантаження. Батьків засмучує той факт, що вони не бачать перспективи розвитку їх життя.

Батьки дітей 3 особливостями розвитку часто переживають критичні життєві ситуації та негативні емоційні переживання, а соціальна фрустрованість є їх постійним супутником.

\section{ЛІТЕРАТУРА}

1. Психологічний та соціально-педагогічний супровід навчання і виховання «особливої дитини» у школі / під заг. ред. Д.Д. Романовської. Чернівці: Технодрук, 2009. 196 с.

2. Соціально-педагогічна робота з батьками, що виховують дітей з особливими потребами: навч. посіб. / за ред. Н.В. Заверико, Т.Г. Соловйова. Запоріжжя: ПП «Тандем», 2008. 53 с.

3. Макаренко I. В. Соціально-педагогічна підтримка батьків дітей раннього віку з особливими потребами: автореф. дис. ...канд. пед. наук: 13.00.05. Луганськ, 2009. 20 с. 
4. Грабовська С. Л. Особливості соціально-психологічної допомоги сім'ям аутичних дітей / С. Л. Грабовська: зб. наук. праць Інституту психології ім. Г. С. Костюка АПН України / за заг. ред. С. Д. Максименка. К., 2009. Т. ХІ, Ч. 2. С. 118-127.

5. Грабовенко Н. В. Соціально-педагогічна робота з сім'ями, що виховують дітей з обмеженими можливостями в умовах реабілітаційного центру: автореф. дис. канд. пед. н.: 13.00.05. Київ, 2008. 24 с.

6. Романчук О. М. Неповносправна дитина в сім'ї та в суспільстві: монографія. Львів: Літопис, 2008. $334 \mathrm{c}$.

7. Лидерс А. Г. Методы психологичекого обследования семьи: монография - практикум. М: Академия, 2007. $432 \mathrm{c.}$

8. Ткачёва В. В. Технологии психологического изучения семей, воспитывающих детей с отклонениями в развитии: монографія. М.: 2006. 320 с.

9. Василюк Ф.Е. Психология переживания. Анализ преодоления критических ситуацій: монография. М.: Изд-во МГУ, 1984. 202 с.

\section{REFERENCES}

1. Psyxologichnyj ta socialno-pedagogichnyj suprovid navchannya i vyxovannya «osoblyvoyi dytyny» $u$ shkoli (2009) [Psychological and socio-pedagogical support of education and upbringing of a "special child" at school] / za red. D.D. Romanovskoyi. Chernivci: Texnodruk, 196 s. [in Ukrainian]

2. Socialno-pedagogichna robota $\mathrm{z}$ bat'kamy, shho vyxovuyut ditej z osoblyvymy potrebamy: navchalnometodychnyj posibnyk (2008) [Socio-pedagogical work with parents raising children with special needs: a textbook] / N.V. Zavery`ko, T.G. Solovjova. - Zaporizhzhya: PP «Tandem», 53 s. [in Ukrainian]

3. Makarenko I. V. (2009) Socialno-pedagogichna pidtrymka batkiv ditej rannogo viku z osoblyvymy potrebamy [Socio-pedagogical support for parents of young children with special needs]: avtoref. dy`s. kand. ped. n.: 13.00.05. Lugans'k, $22 \mathrm{~s}$. [in Ukrainian]

4. Grabovska S. L. (2009) Osoblyvosti socialno-psyxologichnoyi dopomogy simyam autychnyx ditej [Features of social and psychological assistance to families of autistic children] // zb. nauk. pracz Instytutu psyxologiyi im. G. S. Kostyuka APN Ukrayiny`/ za red. S. D. Maksymenka. Ky`yiv, T. XI, Ch. 2. S. 118-127. [in Ukrainian]

5. Grabovenko N. V. (2008) Socialno-pedagogichna robota z simyamy, shho vyxovuyut ditej z obmezhenymy mozhlyvostyamy, v umovax reabilitacijnogo centru [Socio-pedagogical work with families raising children with disabilities in a rehabilitation center]: avtoref. dy`s. ...kand. ped. n.: 13.00.05. Kyiv, 24 s. [in Ukrainian]

6. Romanchuk O. M. (2008) Nepovnospravna dytyna v simyi ta v suspilstvi : monoghrafija. [Disabled child in the family and in society]. Lviv: Litopys, 334 s. [in Ukrainian]

7. Lyders A. G. (2007) Metody psikhologichekogo obsledovaniya sem'i: [Methods of psychological examination of the family]: monografiya - praktikum. Moscow: Akademiya, 432 s. [in Russian]

8. Tkachëva V. V. (2006) Texnologyy psyxologycheskogo yzuchenyya semej, vospytuvayushhyx detej s otklonenyyamy $\mathrm{v}$ razvytyy [Technologies for psychological study of families raising children with developmental disabilities]. Moscow: 320 s. [in Russian]

9. Vasylyuk F.E (1984) Psyxologyya perezhyvanyya. Analyz preodolenyya krytycheskyx sytuacyj [The psychology of experiencing. Analysis of overcoming critical situations]. Moscow: Yzd-vo MGU, 202 s. [in Russian] 